

\section{The English System}

\section{MANCHESTER 1824}

Manchester University Press 
For Pedro and Mio 


\section{The English System}

Quarantine, immigration and the making of a Port Sanitary zone

Krista Maglen

Manchester University Press

Manchester and New York

distributed in the United States exclusively by Palgrave Macmillan 


\section{Copyright @ Krista Maglen 2014}

The right of Krista Maglen to be identified as the author of this work has been asserted by her in accordance with the Copyright, Designs and Patents Act 1988.

Published by Manchester University Press Oxford Road, Manchester M13 9NR, UK and Room 400, 175 Fifth Avenue, New York, NY 10010, USA www.manchesteruniversitypress.co.uk

Distributed in the United States exclusively by Palgrave Macmillan, 175 Fifth Avenue, New York, NY 10010, USA

Distributed in Canada exclusively by UBC Press, University of British Columbia, 2029 West Mall, Vancouver, BC, Canada V6T 1Z2

British Library Cataloguing-in-Publication Data

A catalogue record for this book is available from the British Library

Library of Congress Cataloging-in-Publication Data applied for

\section{ISBN 9780719089657 hardback}

First published 2014

The publisher has no responsibility for the persistence or accuracy of URLs for any external or third-party internet websites referred to in this book, and does not guarantee that any content on such websites is, or will remain, accurate or appropriate.

Typeset

by SPi Publisher Services, Pondicherry, India 